\title{
Analisis Model Tarikan Dan Bangkitan Kendaraan Di Daerah Kecamatan Pemulutan Kabupaten Ogan Ilir
}

\section{Analysis of Vehicle Attraction and Development Model in The Region of Pemulutan District, Ogan Ilir Regency}

\author{
Yunita Mauliana ${ }^{1}$, Diana Nur Afni ${ }^{2}$, Yurina $^{3}$ \\ ${ }^{1,2}$ Program Studi Teknik Sipil Universitas Sang Bumi Ruwa Jurai \\ ${ }^{3}$ Program Studi Teknik Sipil Universitas Bandar Lampung

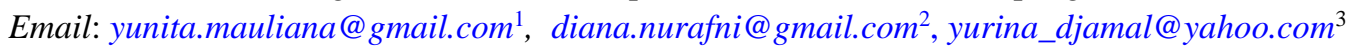

\begin{abstract}
Abstrak
Fungsi dan tata guna lahan pada suatu daerah tentunya akan memenghasilkan bangkitan dan tarikan perjalanan dari dan ke daerah tersebut. Tak terlepas dari hal itu, termasuklah lahan pada daerah pedesaan. Dengan adanya perubahan tata guna lahan, kebutuhan serta karakteristik transportasi juga akan berubah pula. Maka dari itu, dilakukanlah penelitian untuk mendapatkan model bangkitan dan tarikan kendaraan akibat perubahan tata guna lahan di kecamatan Pemulutan. Berdasarkan data-data yang dikumpulkan, didapat model persamaan bangkitan dan tarikan kendaraan menggunakan pendekatan multiple linear regression metode stepwise dapat digambarkan bahwa jalur keluar dan masuk pada saat ini belum berpengaruh terhadap aktivitas system kegiatan di wilayah studi yaitu Jalan Buaya Kecamatan Pemulutan Kabupaten Ogan Ilir.
\end{abstract}

Kata kunci: Analisis Model, Bangkitan dan Tarikan Kendaraan, Kecamatan Pemulutan.

\begin{abstract}
The function and use of land in an area will certainly result in the generation and attraction of travel from and to the area. Apart from that, this includes land in rural areas. With changes in land use, the needs and characteristics of transportation will also change. Therefore, a study was conducted to obtain a model of vehicle generation and towing due to changes in land use in Pemulutan sub-district. Based on the data collected, it can be seen that the vehicle generation and towing equation model using the stepwise multiple linear regression approach can be described that the exit and entry routes currently have no effect on the activity system activities in the study area, namely the crocodile road, Pemulutan sub-district, Ogan Ilir district.
\end{abstract}

Keywords: Model Analysis, Vehicle Generation and Towing, Pemulutan Distric. 


\section{PENDAHULUAN}

Pembangunan infrastruktur jalan suatu wilayah akan meningkat pesat karena adanya pertumbuhan ekonomi dan meningkatnya populasi, sehingga mengakibatkan perkembangan/perubahan guna lahan yang ada pada wilayah tersebut. Perkembangan guna lahan memacu adanya peningkatan aktivitas seperti bekerja, sekolah, belanja, rekreasi dan sebagainya yang mengakibatkan peningkatan arus pergerakan perjalanan manusia, kendaraan maupun barang. Peningkatan arus pergerakan perjalanan ini menjadi bangkitan atau tarikan pergerakan dengan memperlihatkan banyaknya lalu lintas yang terjadi di wilayah tersebut.

Setiap suatu kegiatan pergerakan mempunyai zona asal dan tujuan, dimana asal merupakan zona yang menghasilkan perilaku pergerakan, sedangkan tujuan adalah zona yang menarik pelaku melakukan kegiatan. Jadi terdapat dua pembangkit pergerakan, yaitu : Trip Production (Bangkitan) adalah jumlah perjalananyang dihasilkan oleh suatu zona dan Trip Attraction (Tarikan) adalah jumlah perjalanan yang ditarik oleh suatu zona.

Secara ringkas bangkitan dan tarikan perjalanan dapat diinterpretasikan melalui gambar 1 dibawah ini :

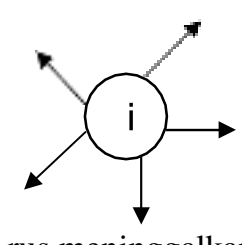

Arus meninggalkan zona i (Bangkitan)

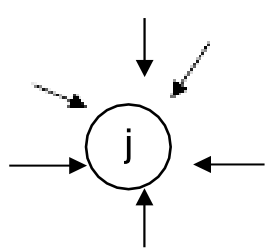

Arus menuju zona j (Tarikan)
Gambar 1. Bangkitan dan Tarikan

Bangkitan lalu lintas adalah banyaknya lalu lintas yang ditimbulkan oleh suatu zone atau daerah per satuan waktu. Jumlah lalu lintas bergantung pada kegiatan kota, karena penyebab lalu lintas adalah adanya kebutuhan manusia untuk melakukan kegiatan berhubungan dan mengangkut barang kebutuhannya [1].

\section{Bangkitan Pergerakan (Trip}

Generation) adalah tahapan pemodelan yang memperkirakan jumlah pergerakan yang berasal dari suatu zona atau tata guna lahan atau jumlah pergerakan yang tertarik ke suatu tataguna lahan atau zona. Tarikan pergerakan adalah jumlah pergerakan yang tertarik ke suatu tata guna lahan atau zona tarikan pergerakan [2].

Trase jalan Tol Palembang-Pemulutan, meskipun sudah diupayakan melalui lahanlahan kosong, namun pada kenyataannnya ada juga yang melintasi infrastruktur jalan lingkungan yang sudah ada, dengan demikian kawasan tersebut akan terjadi perubahan baik terhadap sosial ekonomi masyarakat, perubahan fungsi tata guna lahan maupun perubahan pergerakan lalu lintas pada jalur tersebut.

Pemanfaatan lahan sangat berpengaruh terhadap transportasi yang menjadi penghubung antar guna lahan tersebut, sehingga dengan adanya pergerakan transportasi ini kita dapat memperkirakan jumlah dan lokasi kebutuhan transportasi pada masa yang akan datang, termasuk jumlah perjalanan baik untuk angkutan umum maupun angkutan pribadi. Jumlah dan lokasi transportasi ini berguna untuk kepentingan kebijaksanaan investasi perencanaan transportasi yang lebih efektif, efisien dan ekonomis. Dengan demikian maka diperlukan adanya pemodelan bangkitan dan tarikan pergerakan kendaraan. Dimana pemodelan ini bertujuan untuk mengestimasi seakurat mungkin bangkitan dan tarikan lalu lintas masa sekarang yang digunakan untuk memprediksi tata guna lahan di masa yang akan datang.

Dalam melaksanakan penelitian ini telah dikaji terlebih dahulu penelitianpenelitian sebelumnya, yaitu : Penataan Perkembangan Tata Guna Lahan pada Jalan Tol Makassar [3]; Analisis Model Bangkitan Tarikan Kendaraan Pada Sekolah Swasta di Zona Pinggiran Kota di Kota Makasar [4]; Analisis Bangkitan dan Tarikan Perjalanan 
(Studi Kasus Pada Tata Guna Lahan Rumah Sakit Umum di Klaten [5].

Berdasarkan latar belakang yang telah dikemukakan di atas, maka dibuat rumusan masalah sebagai berikut: 1) Bagaimana karakteristik pergerakan penduduk Kecamatan Pemulutan Kabupaten Ogan Ilir; 2) Bagaimana model bangkitan perjalanan dari lahan Kecamatan Pemulutan Kabupaten Ogan Ilir; 3) Bagaimana besaran faktor-faktor yang menentukan jumlah perjalanan kendaraan di daerah Kecamatan Pemulutan Kabupaten Ogan Ilir.

Tujuan dari penelitian ini adalah : 1) Mengetahui karakteristik pergerakan penduduk Kecamatan Pemulutan Kabupaten Ogan Ilir; 2) Mengetahui model bangkitan dan tarikan perjalanan dari lahan Kecamatan Pemulutan Kabupaten Ogan Ilir; 3) Mengetahui besaran faktor-faktor yang menentukan jumlah perjalanan kendaraan di daerah Kecamatan Pemulutan Kabupaten Ogan Ilir.

\section{METODE PENELITIAN}

\section{Data Primer}

Teknik pengambilan sample ada dua cara, yang pertama adalah teknik acedental sampling, yang mana pengambilan sample dari populasi dengan cara kebetulan dapat di jumpai dan bersedia dimintai informasi. Peneliti dapat memilih orang/responden yang terdekat dengannya atau yang pertama kali dijumpai dan seterusnya yang berdasarkan atas kriteria atau pertimbangan tertentu. Teknik yang kedua, untuk mendapatkan jumlah sample yaitu dengan menggunakan rumus Slovin.

Rumus Slovin adalah :

$$
\mathrm{n}=\frac{\mathrm{N}}{1+\mathrm{N}(\mathrm{e})^{2}}
$$

Dimana :

$\mathrm{n}=$ Sample

$\mathrm{N}=$ Populasi $\mathrm{e}=$ Interval Keyakinan (biasanya 0.05 atau $0.01)$

Dalam penelitian ini, peneliti menggunakan teknik yang kedua, yaitu dengan menggunakan rumus Slovin, dimana nilai interval keyakinan ditentukan 0.05 .

\section{Data Sekunder}

Pada penelitian ini data yang dibutuhkan dapat diperoleh dari kantor Kecamatan Pemulutan Kabupaten Ogan Ilir yaitu data Statistik Kecamatan Pemulutan dalam angka tahun 2018 yang tertuang dalam buku Badan Pusat Statistik (BPS) Kecamatan Pemulutan Kabupaten Ogan Ilir tahun 2018 [6].

Bagan alir ini bertujuan mengarahkan dan sebagai pedoman dalam pelaksanaan jalannya penelitian sehingga mendapatkan hasil yang terarah dan sesuai dengan yang diinginkan oleh peneliti. Untuk lebih detilnya metodologi penelitian yang akan dilaksanakan dapat dilihat pada gambar di bawah ini : 


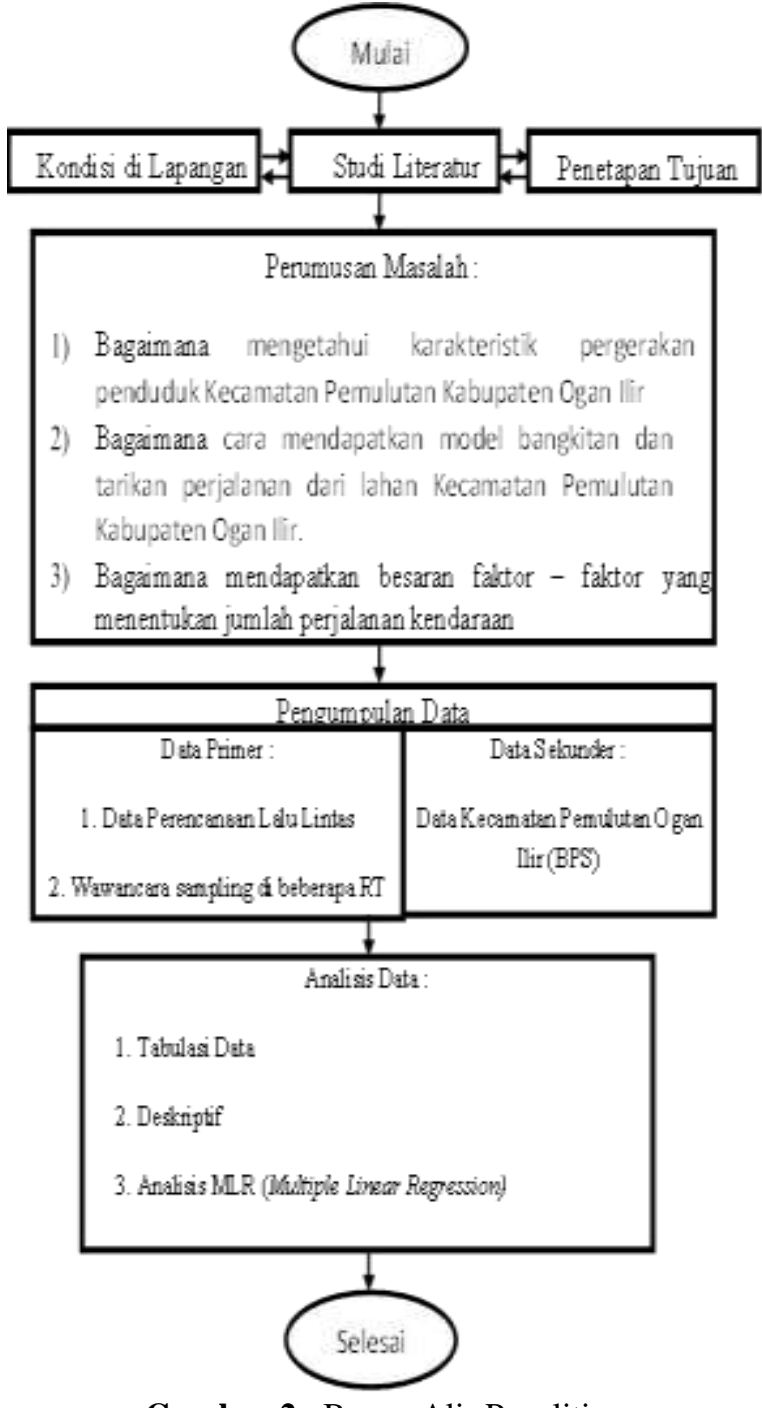

Gambar 2. Bagan Alir Penelitin

Berdasarkan data-data yang telah dikumpulkan, kemudian diolah dan dianalisis menggunakan pendekatan MLR (Multiple Linear Regression) menggunakan metode regresi Stepwise yaitu suatu metode untuk mendapatkan model terbaik dari sebuah analisis regresi.

\section{HASIL DAN PEMBAHASAN}

\section{Karakteristik Perjalanan Penduduk Kecamatan Pemulutan}

Karakteristik perjalanan penduduk di Kecamatan Pemulutan khususnya sepanjang Jalan Buaya yang merupakan lokasi penelitian memiliki berbagai macam karakteristik. Ada 4 desa yang mewakili dari 25 desa sebagai sampel untuk mengetahui karakteristik perjalanan penduduknya yaitu : 1) Desa Simpang Pelabuhan Dalam; 2) Desa Pelabuhan Dalam; 3) Desa Pemulutan Ulu; 4) Desa Teluk Kecapi.

Data-data yang di survey untuk mengetahui karakteristik perjalanan di Kecamatan Pemulutan ini adalah data- data yang mempengaruhi bangkitan dan tarikan pergerakan kendaraan yaitu : 1) Pekerjaan warga; 2) Umur; 3) Pendidikan; 4) Penghasilan; 5) Jumlah kendaraan motor dan 6) Jumlah kendaraan mobil.

\section{Model bangkitan dan tarikan perjalanan}

Untuk mendapatkan persamaan model bangkitan dan tarikan perjalanan dengan menggunakan Analisis Regresi Linier Berganda dengan metode stepwise, dimana analisa ini di gunakan untuk memodelkan hubungan antara variable dependent (terikat) dengan variable independent (bebas), dengan jumlah variable independent lebih dari satu.

Metode Stepwise adalah metode dengan memasukkan predictor secara bertahap berdasarkan nilai $\mathrm{F}$ yang signifikan (sig $\mathrm{F}$ di bawah 0.05). Setelah di masukkan lalu di keluarkan lagi. Proses memasukkan dikombinasikan dengan mengeliminasi predictor yang tidak signifikan atau dengan kata lain kita sudah langsung bisa mendapatkan hasil yang signifikan dari model yang dikeluarkan.

Untuk melakukan pemodelan ini, digunakan persamaan sebagai berikut :

$$
\mathrm{Y}=\mathrm{A}+\mathrm{B}_{1} \cdot \mathrm{X}_{1}+\mathrm{B}_{2} \cdot \mathrm{X}_{2}+\ldots . .+\mathrm{B}_{\mathrm{Z}} \mathrm{X}_{\mathrm{Z}}
$$

Dimana :

$\mathrm{Y} \quad=$ Faktor tidak bebas/terikat

$\mathrm{X}_{(1-\mathrm{Z})}=$ Faktor bebas

$\mathrm{A} \quad=$ Konstanta regresi

$\mathrm{B}_{(1-\mathrm{Z})}=$ Koefisien regresi 
Dari jumlah faktor-faktor yang dianggap signifikan terhadap bangkitan dan tarikan pergerakan dalam membuat pemodelan jumlah di gunakan data sekunder yaitu Buku BPS data Kabupaten Pemulutan dalam angka tahun 2018. Dimana dari data- data tersebut di golongkan data-data bangkitan atau tarikan untuk di lihat signifikannya dengan menggunakan program SPSS sehingga terbentuk suatu persamaan yang linier, seperti yang tampak pada tabel 1:

Tabel 1. Descriptive Statistics

\begin{tabular}{lccc}
\hline & Mean & Std. Deviation & N \\
\hline Bangkitan & $1.3668 \mathrm{E} 2$ & 68.98896 & 25 \\
\hline Jumlah Penduduk & $1.7691 \mathrm{E} 3$ & 780.85236 & 25 \\
\hline Jumlah Rumah Tangga & $4.2508 \mathrm{E} 2$ & 159.61514 & 25 \\
\hline Jumlah Pegawai Negeri & 8.8800 & 6.91207 & 25 \\
\hline Jumlah Jasa & 62.5200 & 27.97934 & 25 \\
\hline Jumlah yg Bekerja & $3.2752 \mathrm{E} 2$ & 156.18048 & 25 \\
\hline Jumlah Mobil & 16.6400 & 15.54799 & 25 \\
\hline Jumlah Motor & $1.4840 \mathrm{E} 2$ & 77.77960 & 25 \\
\hline
\end{tabular}

Tabel 2. Correlations

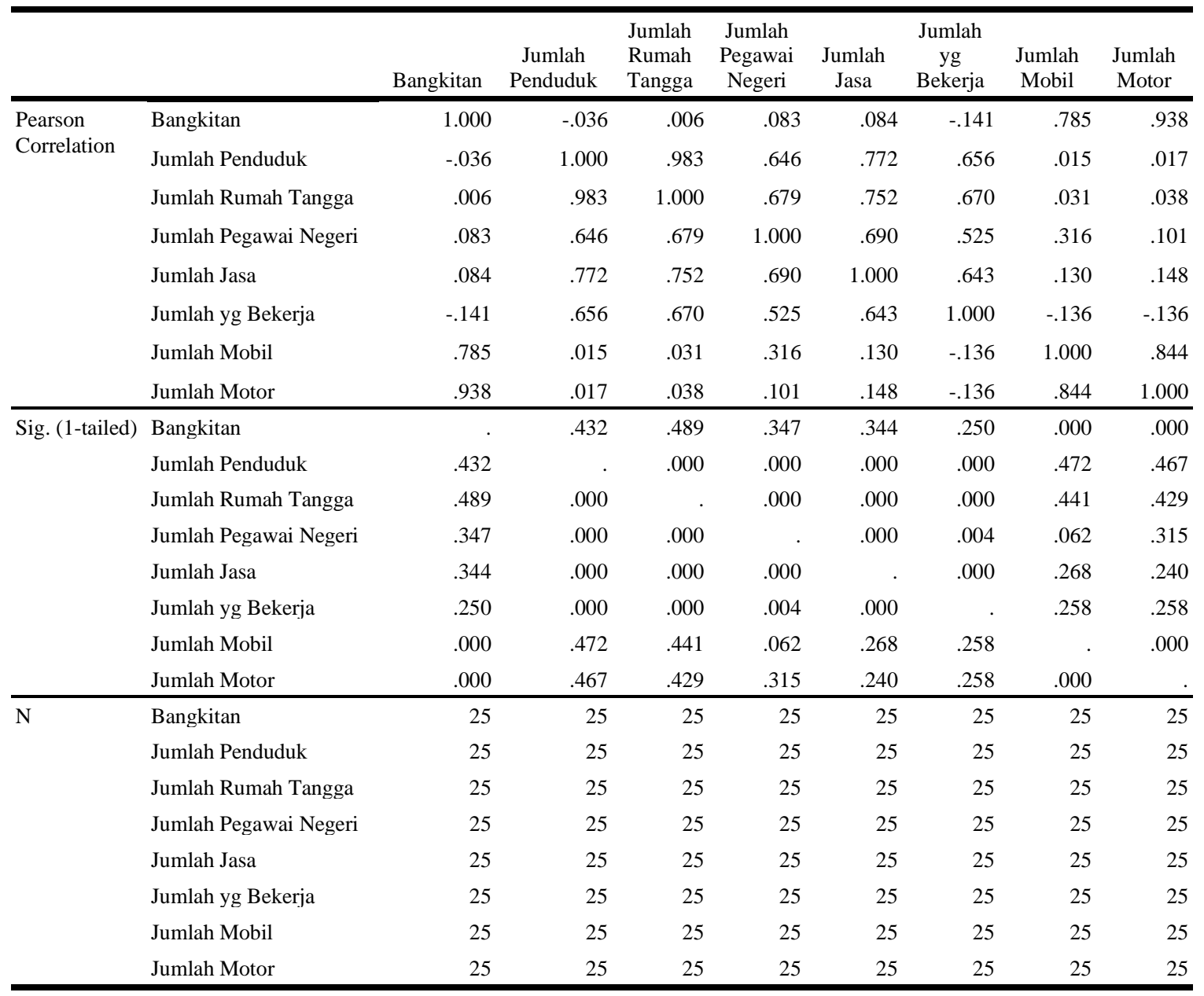


Tabel 3. Analisis Regresi Linier Metode Stepwise

\begin{tabular}{|c|c|c|c|}
\hline \multicolumn{4}{|c|}{ Variables Entered/Removed $^{a}$} \\
\hline Model & Variables Entered & Variables Removed & Method \\
\hline 1 & Jumlah Motor & & $\begin{array}{l}\text { Stepwise (Criteria: Probability-of-F-to-enter }<= \\
.050 \text {, Probability-of-F-to-remove }>=.100) .\end{array}$ \\
\hline
\end{tabular}

a. Dependent Variable: Bangkitan

Terlihat dari tabel diatas, analisis regresi linier metode stepwise dengan probalitas lebih kecil atau sama dengan 0.05

Tabel 4. Korelasi R Pada Analisis Regresi Linier

\begin{tabular}{|c|c|c|c|c|c|c|c|c|c|c|}
\hline \multirow{3}{*}{ Model } & \multicolumn{9}{|c|}{ Model Summaryb } & \multirow{3}{*}{$\begin{array}{l}\text { Durbin- } \\
\text { Watson }\end{array}$} \\
\hline & & & & & \multicolumn{5}{|c|}{ Change Statistics } & \\
\hline & $\mathbf{N}$ & Square & Square & the Estimate & $\begin{array}{l}\text { R Square } \\
\text { Change }\end{array}$ & F Change & df1 & df 2 & $\begin{array}{l}\text { Sig. F } \\
\text { Change }\end{array}$ & \\
\hline 1 & $.938^{\mathrm{a}}$ & .879 & .874 & 24.51805 & .879 & 167.020 & 1 & 23 & .000 & 1.902 \\
\hline
\end{tabular}

a. Predictors: (Constant), Jumlah Motor

b. Dependent Variable : Bangkitan

Tabel di atas menjelaskan besarnya nilai korelasi/hubungan $\mathrm{R}$ yaitu sebesar 0.938 dan di jelaskan besarnya prosentase pengaruh variabel bebas terhadap variabel terikat yang disebut koefisien determinanasi yang merupakan hasil dari penguadratan R. Dari output tersebut di menunjukkan bahwa variabel yang di gunakan dalam model tarikan pergerakan adalah jumlah motor. peroleh koefisien determinasi $\left(\mathrm{R}^{2}\right)$ sebesar 0.879 yang mengandung pengertian bahwa pengaruh variabel bebas (motor) terhadap variabel terikat (model Tarikan) adalah sebesar 64\% sedangkan sisanya di pengaruhi oleh variabel lain.

Tabel 5. Pengaruh variabel motor terhadap Tarikan pergerakan

\begin{tabular}{|c|c|c|c|c|c|c|}
\hline \multicolumn{7}{|c|}{ ANOVA $^{b}$} \\
\hline & Model & Sum of Squares & $\mathrm{df}$ & Mean Square & $\bar{F}$ & Sig. \\
\hline \multirow{3}{*}{1} & Regression & 100401.341 & 1 & 100401.341 & 167.020 & $.000^{\mathrm{a}}$ \\
\hline & Residual & 13826.099 & 23 & 601.135 & & \\
\hline & Total & 114227.440 & 24 & & & \\
\hline
\end{tabular}

a. Predictors: (Constant), Jumlah Motor

b. Dependent Variable : Bangkitan

Pada bagian ini, menjelaskan apakah ada pengaruh yang nyata (signifikan) variabel motor terhadap Tarikan pergerakan. Dari output terlihat bahwa F

Tabel 6. Pengaruh variabel motor terhadap Bangkitan pergerakan

\begin{tabular}{|c|c|c|c|c|c|c|c|c|c|}
\hline \multicolumn{10}{|c|}{ Coefficients $^{\mathbf{a}}$} \\
\hline & $\begin{array}{l}\text { Mo } \\
\text { del }\end{array}$ & \multicolumn{2}{|c|}{$\begin{array}{r}\text { Unstandardized } \\
\text { Coefficients } \\
\end{array}$} & $\begin{array}{c}\begin{array}{r}\text { Standardized } \\
\text { Coefficients }\end{array} \\
\text { Beta }\end{array}$ & $\mathrm{t}$ & Sig. & \multicolumn{3}{|c|}{ Correlations } \\
\hline \multirow{2}{*}{1} & (Constant) & 13.275 & 10.734 & & 1.237 & .229 & & & \\
\hline & Jumlah Motor & .832 & .064 & .938 & 12.924 & .000 & .938 & .938 & .938 \\
\hline
\end{tabular}


Output bagian empat ini $\left(\right.$ Coefficients $\left.^{\mathrm{a}}\right)$, pada kolom B didapat konstanta (A) adalah 13,275 , sedang nilai motor $\left(\mathrm{X}_{7}\right)$ adalah 0.64 , sehingga persamaan regresi yang di hasilkan adalah :

$$
\begin{aligned}
& \mathrm{YB}(\text { Bangkitan })=\mathrm{A}+\mathrm{B} 1 . \mathrm{X} 7 \\
& \mathrm{Y}_{\mathrm{B}(\text { Bangkitan })}=39.394+0.64 \mathrm{X}_{7}
\end{aligned}
$$

Koefisien $\mathrm{B}_{1}$ dinamakan keofisien arah regrasi dan menyatakan perubahan nilai $\mathrm{Y}_{\mathrm{B} \text { (Bangkitan), dimana untuk setiap perubahan }}$ variable sebesar satu satuan menjadi bertambahnya nilai pergerakan.

Sehingga dari persamaan tersebut dapat diterjemahkan :

1. Konstanta sebesar 13,275 menyatakan bahwa jika jumlah motor tetap atau mengalami penambahan atau pengurangan, maka jumlah bangkitan pergerakan sebesar nilai konstanta yaitu tidak 13,275.

2. Koefisien regresi $\mathrm{X}_{7}$ sebesar 0.832 menyatakan bahwa setiap penambahan jumlah motor satu satuan maka variable jumlah motor akan naik sebesar 0.832. Dengan asumsi bahwa variable bebas yang lain dari model regresi adalah tetap.

Selain menggambarkan persamaan regresi output ini juga menampilkan uji signifikansi dengan uji t yaitu mengetahui apakah ada pengaruh yang nyata (signifikan) antara variable jumlah kepemilikan motor $\left(\mathrm{X}_{7}\right)$ terhadap bangkitan Pergerakan YB (Bangkitan).

Ho : Tidak ada pengaruh yang nyata (signifikan) variable jumlah kepemilikan Motor $\left(\mathrm{X}_{7}\right)$ terhadap variable bangkitan pergerakan $\left(\mathrm{Y}_{\mathrm{B}}\right)$ sedangkan $\mathrm{H} 1$ : Ada pengaruh yang nyata (signifikan) variable jumlah kepemilikan Motor $\left(\mathrm{X}_{7}\right)$ terhadap variable bangkitan pergerakan $\left(\mathrm{Y}_{\mathrm{B}}\right)$.

Dari output di atas dapat diketahui nilai $\mathrm{t}$ hitung $=12,924$ (lihat table Coefficients) sedangkan $\mathrm{t}$ kritis dapat di cari pada tabel statistik yaitu tabel t pada signifikansi $0.05 / 2$ $=0.025$ (uji 2 sisi) dengan $\mathrm{df}=\mathrm{n}-2$ atau 25 $2=23$, maka di dapat $\mathrm{t}$ kritis adalah 2.069. Sehingga $t$ hitung $\leq \mathrm{t}$ kritis jadi Ho diterima dan apabila t hitung $>\mathrm{t}$ kritis jadi Ho ditolak. Kesimpulannya adalah t hitung $(12,924)>\mathrm{t}$ kritis (2.069) jadi hipotesis 0 di tolak.

Berdasarkan uraian serta analisa data yang telah dilakukan dapat diketahui bahwa

1. Karakteristik pergerakan penduduk kecamatan Pemulutan Kabupaten Ogan Ilir adalah :

a. Sampel Desa Simpang Pelabuhan Dalam

i) Wiraswasta : $40.74 \%$

ii) Usia $31-41$ th $: 38,89 \%$

iii) Pendidikan SMP : $35,19 \%$

iv) Penghasilan : Rp.1.000.000,s/d. Rp. 1.500.000,- sebanyak $24,07 \%$

v) Jumlah Kendaraan Roda 4 : $92,59 \%$ tidak memiliki kendaraan roda 4

vi) Jumlah Kendaraan Roda 2 : $53,70 \%$ memiliki 1 kendaraan roda 2

b. Sampel Desa Pelabuhan Dalam
i) Wiraswasta
: $30.77 \%$
ii) Usia $31-41$ th
$: 32,69 \%$
iii) Pendidikan SMP $: 36,54 \%$
iv) Penghasilan : Rp.1.000.000,- s/d. Rp. 1.500.000,- sebanyak $20,51 \%$
v) Jumlah Kendaraan Roda 4 : $88,46 \%$ tidak memiliki kendaraan roda 4 
vi) Jumlah Kendaraan Roda 2 : $60,62 \%$ memiliki 1 kendaraan roda 2

c. Sampel Desa Pemulutan Ulu
i) Wiraswasta :39,81\%
ii) Usia 31-41 th : $35,19 \%$
iii) Pendidikan SMP : $36,11 \%$
iv) Penghasilan : Rp.0,- s/d. Rp. 500.000,- sebanyak 33,33\%
v) Jumlah Kendaraan Roda 4 : 93,52\% tidak memiliki kendaraan roda 4
vi) Jumlah Kendaraan Roda 2 : $63,89 \%$ memiliki 1 kendaraan roda 2

d. Sampel Desa Teluk Kecapi
i) Wiraswasta
: $29,86 \%$
ii) Usia $31-41$ th $: 33,33 \%$
iii) Pendidikan SMP : 38,89\%
iv) Penghasilan : Rp.0,- s/d. Rp. 500.000,- sebanyak 22,92\%
v) Jumlah Kendaraan Roda 4 : $88,89 \%$ tidak memiliki kendaraan roda 4.
vi) Jumlah Kendaraan Roda 2 : 67,36\% memiliki 1 kendaraan roda $267,36 \%$ memiliki 1 kendaraan roda 2.

2. Berdasarkan hasil analisa regresi linier, di dapat persamaan untuk Tarikan Pergerakan seoerti berikut : $\mathrm{Y}_{(\text {Tarikan })}=$ $39.394+0.641 \mathrm{X}_{8}$ dengan variable $\mathrm{X}_{8}$ merupakan jumlah kepemiklikan motor. Untuk Bangkitan pergerakan di dapat persamaan $\mathrm{Y}_{(\text {Bangkitan })}=13.275+0.832$ $\mathrm{X}_{8}$ dengan $\mathrm{X}_{8}$ merupakan jumlah kepemilikan motor.

Dari persamaan Model Tarikan dan Bangkitan diatas factor yang dominan adalah jumlah kepemilikan motor.

Dalam penelitian ini dapat diketahui bagaimana karakteristik pergerakan penduduk serta faktor apa saja yang dominan dalam menentukan jumlah perjalanan kendaraan di daerah Kecamatan Pemulutan Kabupaten Ogan Ilir sehingga dapat ditentukan model bangkitan dan tarikan kendaraan akibat perubahan tata guna lahan saat ini. Hal ini berbeda dengan beberapa penelitian yang pernah dilakukan sebelumnya, antara lain : 1) Penataan Perkembangan Tata Guna Lahan pada Jalan Tol Makassar (Muh. Syahrizal, 2012). Penelitian ini berisi tentang cara mencari keseimbangan antara tata guna lahan dengan kemampuan infrastruktur penunjang yang ada pada daerah tersebut; 2) Analisis Model Bangkitan Tarikan Kendaraan Pada Sekolah Swasta di Zona Pinggiran Kota di Kota Makasar (Andri Asto Rumanga, 2014). Penelitian ini membuat pemodelan bangkitan dan tarikan pergerakan moda penghantar siswa pada sekolah-sekolah swasta di kota Makassar; 3) Analisis Bangkitan dan Tarikan Perjalanan (Studi Kasus Pada Tata Guna Lahan Rumah Sakit Umum di Klaten (Wahyuningsih AR, Riyanto Agus, dan Munawar Ahmad, 2015). Penelitian ini membuat model tarikan dan bangkitan perjalanan yang di timbulkan oleh tata guna lahan rumah sakit di Klaten dengan perbandingan terhadap hari kerja dan hari minggu yang dipengaruhi oleh banyaknya karyawan, banyaknya tempat tidur rawat inap, banyaknya poliklinik dan luas lahan parkir.

\section{KESIMPULAN}

Berdasarkan uraian serta analisa data yang telah dilakukan, dapat ditarik kesimpulan bahwa : jumlah kepemilikan motor $\left(\mathrm{X}_{7}\right)$ berpengaruh terhadap bangkitan pergerakan. Nilai koefisien dan $\mathrm{t}$ hitung adalah positif sehingga jumlah motor terhadap bangkitan pegerakan. Berdasarkan kesimpulan di atas, dapat digambarkan bahwa jalur keluar dan masuk pada saat ini belum berpengaruh terhadap aktivitas system kegiatan di wilayah studi yaitu jalan buaya kecamatan Pemulutan Kabupaten Ogan Ilir.

Dari kesimpulan tersebut, dapat diberikan saran untuk penelitian berikutnya, 
antara lain : masih perlu kajian rencana pengembangan kegiatan, tata guna lahan dan potensi daerah setempat dalam hal ini Kecamatan Pemulutan serta memperbanyak sampel pengamatan serta menambahkan variable-variabel lain yang memungkinkan agar model persamaan dapat memberikan hasil yang lebih baik.

\section{DAFTAR PUSTAKA}

[1] Suwardjoko Merencanakan

Warpani, sistem perangkutan. 1990.

[2] O. Z. Tamin, Perencanaan dan Pemodelan Transportasi. 2000.

[3] M. Syahrizal R., S. Rauf, and P. Mubassirang, "Pemetaan Perkembangan Tata Guna Lahan Pada Jalan Tol Kota Makassar," J. Penelit. Jur. Sipil Fak. Tek. Univ. Hasanuddin, 2012.

[4] A. A. Rumanga, "Analisis Model Bangkitan Tarikan Kendaraan Di Kota Makassar Disusun Oleh: Andri Asto Rumanga," Anal. Model Bangkitan Tarikan Kendaraan Di Kota Makassar Disusun Oleh Andri Asto Rumanga, p. 56, 2014.

[5] A. Imam, "ANALISIS BANGKITAN DAN TARIKAN PERJALANAN (Studi Kasus Pada Tata Guna Lahan Rumah Sakit Umum di Klaten)," J. Chem. Inf. Model., vol. 53, no. 9, pp. 16891699, 2013.

[6] Badan Pusat Statistik, Kabupaten Ogan Ilir Dalam Angka. BPS Kabupaten Ogan Ilir, 2018. 